\title{
EREBEA
}

Revista de Humanidades

y Ciencias Sociales

NúM. 5 (2015), pp. 121-154

ISSN: 0214-0691

\section{Religión e Identidad en Asia Central}

\author{
Alejandro Colete Moya \\ Universidad de Sevilla
}

RESUMEN

Este artículo pretende argumentar que el uso del concepto de "religión" en la historiografía debe ser eliminado, y que el concepto de "conversión" debe ser también matizado, si no redefinido por entero. Se propone el uso de "concepción" o "paradigma” para sustituir "religion”.

Palabras Clave

Religión; conversión; Asia Central; nomadismo; sedentarismo; Kuhn; Wittgenstein.

Fecha de recepción: 24 de sept. de 2015

Fecha de aceptación: 30 de octubre de 2015

\section{Abstract}

This paper argues that the use of the concept "religion" in historiography ought to be ended, and that the concept of "conversion" ought also to be nuanced, if not entirely redefined. In lieu of "religion," the use of the more accurate "conception" or "paradigm" is proposed.

\section{KEYWORDS}

religion; conversion; Central Asia; nomadism; sedentism; Kuhn; Wittgenstein. 



\section{INTRODUCCIÓN}

Lo que sigue en adelante son una serie de reflexiones que surgen de múltiples perplejidades aparecidas tras varias lecturas de historia de Asia Central, concretamente en la historia que se concentra entre lo siglos V-VIII y XI-XIII. Este artículo es, por decirlo así, como yo he logrado resolverme dudas o dificultades a la hora de entender una serie de fenómenos de los que hablaré brevemente antes de pasar a las soluciones terminológicas que me he procurado. Pese a que todo surge de esta serie de lecturas sobre Asia Central, me gustaría dejar claro que: primero, las soluciones que he propuesto son universales, al menos hasta que alguien demostrase lo contrario, y pongo ejemplo de su alcance allende las fronteras de Asia Central. Segundo, aunque el lector se vea abrumado con más información histórica de la que le pueda interesar, recuerde que lo importante es el final del camino: este texto no pretende decir nada nuevo sobre la historia de los pueblos turco-mongoles ni nada nuevo sobre la historia del Tibet, por ejemplo. Lo importante son las reflexiones de fondo acerca de la religión. Para terminar esta breve introducción, he de decir que este artículo era muy amplio, y tuve que recortar, de modo que difícilmente se puede considerar que este texto sea uno pulido y completo. Espero algún día poder dedicar a la cuestión todo el espacio que se merece, que es mucho más de lo que yo pueda dedicarle aquí.

\section{Parte i.}

¿CUÁL ES EL PROBLEMA?

\section{EL FENÓMENO}

Asia Central, en torno al año 550 d.C., es un verdadero hervidero de imperios: los turcos logran poner en pie su primer y efímero jaanato ${ }^{1}$, los Tibetanos se lanzan a conquistar el mundo e incluso a plantarle cara a China, mientras que ésta a su vez se une contra los turcos bajo el estandarte de los Sui. Persas y Bizantinos, agentes importantes en Asia Central, también querrán imponer sus intereses. Comienza entonces una guerra sin cuartel que dura unos 200 años. El resultado no podría ser más "extraño": China, bajo otra nueva dinastía (la Tang), ha sufrido un

1 "Jaanato" está traduciendo "qağanate" tal y como lo usan Golden entre otros. Dado que la "q" traslitera un sonido similar a la jota española y que la " $\mathrm{g}$ " del turco no hace sino alargar la vocal anterior, usaré "jaán” para trasliterar el inglés "khan” o el mongol "qağan”. Cf., P. Golden, An introduction to the History of the Turkic, Visbaden, 1992, Otto Harrassowitz. 
asalto del que duramente se recuperará; los imperios turcos extintos y sustituidos por los Uigures, los musulmanes totalmente renovados tras la revolución abbasí, pero impotentes ante el progresivo desmembramiento posterior del califato; los Tibetanos al borde de la aniquilación y con una revolución interna que acaba en la adopción del Budismo como religión oficial; y todo el actual turquestán ex-soviético como área de influencia del Islam tras la batalla de Talas $(715)^{2}$. Los Uygures, tomarán el signo de los maniqueos y sus emperadores se tendrán por "emanaciones de Mani"; ; los Jázaros, facción turca separada desde tiempos del primer imperio turco, tomarán el judaísmo como religión oficial tras haber sido invadidos por los musulmanes ${ }^{4}$; los tibetanos escogerán el Budismo mahayana tras la revolución que encabezaron los ministros que servían a la dinastía en el poder ${ }^{5}$; por último los árabes, en esta misma época, sufrirán la revolución abbasí, generando una nueva entidad política más definida que aquella que se tenía en tiempos omeyas ${ }^{6}$. Mi perplejidad se puede formular con esta pregunta: ¿cómo exactamente deberíamos interpretar estos fenómenos históricos? Budismo, Nestorianismo, Maniqueísmo, Islam, Judaísmo... Llevaban mucho tiempo ya circulando (no tanto en el caso del Islam) y era común encontrar en cualquiera de los bandos a súbditos de todas estas religiones: el estado, o la institución política que gobernaba la comunidad, no manifestaba de suyo ninguna religión particular desde su nacimiento, pero en cambio parece conveniente adoptar una religión de estado después de unos 200 ańos desde la generación de esas nuevas instituciones políticas. Desde que los nuevos jugadores se ponen sobre la mesa, comienzan a luchar entre sí por el control de ciertas áreas de importancia económica vital no ya para la supervivencia, sino para la hegemonía de muchas de esas comunidades. Tras aproximadamente doscientos ańos, llegan una serie de revoluciones que terminan todas en la elección de una religión estado y en una renovación del impulso que, finalmente, será efímera si no fútil, dado que el daño económico ya estaba hecho.

2 Esta parte histórico-política del trabajo estaba más ampliada en el primer borrador del artículo, y por razones de espacio tuve que recortar esta parte. En cualquier caso, véase para ampliar información: para estos 200 años, desde el punto de vista tibetano C. I. Beckwith, The Tibetan Empire in Central Asia, Pinceton, 1987, Princeton University Press. Para el primer y segundo imperio turco: Golden, íbid. 124-141, también R. Grousset, The Empire of the Steppes: a History of Central Asia, New Jersey, 1970, Rugers University, 87-93. Sobre la penetración árabe en la zona: C. Cahen, El Islam I. Desde los orógenes hasta el comienzo del Imperio Otomano, Madrid, 2002, Historia Universal Siglo XXI, 27-28 y también G. Hambly, Asia central, Madrid, 2010, Siglo XXI, 67-68. En general, Beckwith, Empires of the Silk Road, Pinceton, 2009, Princeton Univ. Press, cap. 5 y 6 son muy buenos y contienen una perfecta explicación de los fenómenos geo-políticos de este momento histórico entre el 550 y el 750.

3 Grousset, op. cit., 21.

4 Beckwith, Empires...149.

5 Beckwith, The Tibetan...: 140-142.

6 Beckwith, Empires... 146. Cahen, op. cit., 57. 
Con el fenómeno a solas, podemos llegar a esta conclusión: una comunidad con algún grado de cohesión social, por si misma, carece de una identidad clara, sino que más bien esa identidad se forma mejor cuando se ha contrapuesto a otra comunidad diferente. Entonces la comunidad se afirma a sí misma: pero cuando afirmamos algo estamos del mismo modo diciendo no a muchas cosas, particularmente, a todas las demás. De modo que la elección de una religión de estado, sobretodo si es diferente a la que ostentan los demás grupos/ comunidades de la zona, debe ser interpretada como un gesto de afirmación de sí por parte de una comunidad de ciudadanos. El grado de severidad de esta afirmación dependerá en gran medida del carácter particular de ese pueblo: así, los chinos parecen reaccionar de un modo muy violento a la hora de "afirmarse". Tras la revolución de An $\mathrm{Lu}-\mathrm{Shu}^{7}$, todos los no-chinos fueron masacrados ${ }^{8}$, como sucedería más adelante cuando la dinastía Ming, nacida tras las conquistas de Kublay, se dedicase a la destrucción masiva de cualquier no-chino desde el cantón hasta la Gran Muralla, llegando también a prohibir el Cristianismo, que ya estaba en cierta medida extendido por la zona ${ }^{9}$. Con esto los Chinos estaban mandando un mensaje: «somos una comunidad y han venido otros, y echaremos a esos otros, porque expulsando a ese otro me estoy al mismo tiempo afirmando como una comunidad con poder». Pensemos en el caso chino en dos cosas: la religión es religión nacional, de estado, y el emperador, que es la manifestación de la constitución política de esta comunidad, es siempre "Hijo del Cielo", que es un título religioso al tiempo que político ${ }^{10}$. Conocido esto, ¿cómo iban los cristianos a ser parte de esta comunidad (en sentido político) si no reconocen como "Hijo del Cielo" al emperador?, ser cristiano o musulmán es, sencillamente, no reconocer simultáneamente la constitución política de China y lo que los chinos tienen como sagrado, y por eso los chinos más tradicionales se podían sentir amenazados por gentes de otra religión. Mi pregunta es, entonces, ¿qué diferencia hay entre constitución política, comunidad, cultura y religión?. Los Uigures, o los nómadas en general, no parecen haber sido tan violentos, sino de hecho muy tolerantes en lo que se refiere a la religión, lo que no quita que no tuviesen noción de religión de estado, pero de esto hablaremos más adelante. El interés descansa por tanto en lo siguiente: primero, ¿qué añade una religión a una comunidad de ciudadanos para que ésta se decida espontáneamente por una u otra?; segundo, ¿qué manifiesta esta decisión por parte de una comunidad?;

7 Es la revolución que hemos mencionado antes y que deja en muy débil condición a la dinastía Tang. Beckwith, The Tibetan... 142. Beckwith, Empires... 145-146.

8 Beckwith, íbid., 150.

9 Grousset, op. cit., 319. Para la revolución Ming para expulsar a los Mongoles, ibídem, 320325.

10 Díez de Velasco, Introducción a la historia de las religiones, Madrid, 2002, Trotta, 192. El Emperador participaba y ejecutaba el rito más importante en el calendario chino, con lo que se reafirma la idea de que la constitución política y religiosa están ligadas. Ibídem, 195. 
tercero, ¿̨cómo es posible la conversión misma, esto es, que una religión originada en otra cultura brille allende las fronteras de la misma?

\section{RELIGIÓN DE ESTADO}

Religión no puede significar, al menos exclusivamente, relación de un hombre con Dios, o la creencia en un Dios (o en dos centenares de ellos) o en una mera distinción entre lo sagrado y lo profano, ni tampoco puede ser exclusivamente una experiencia ante el "misterio tremendo" como han insistido autores como Elíade $^{11}$, siguiendo en este caso a Rudolf $\mathrm{Otto}^{12}$. Ni siquiera podrá ser sólo la suma de estas cosas, porque ni cada una por separado ni el conjunto de todas ellas nos ilustran adecuadamente sobre los fenómenos de los que tendrían que dar cuenta a la hora de la explicación de un suceso histórico o de una cadena de sucesos. Los Uygures tenían su propia manera de relacionarse con sus Dioses, lo que no implicaba la decisión de esta comunidad de tener como religión de estado su Chamanismo o de algo parecido, si quiera, a lo que podríamos concebir sin anacronismos como "religión de estado". Esto también pasaba con los Jázaros, que no se convirtieron al Judaísmo hasta después de haber sido invadidos por los musulmanes; o los Tibetanos, los últimos en convertirse, que curiosamente se convierten a una religión que no es ninguna de las que les rodean. ¿Qué es adoptar una religión de estado?, pues manifestar al público que de facto y a todos los efectos esa comunidad responde ante las demás de una manera y no lo hará de otra. Es decir, la religión de estado manifiesta las creencias de un sector de la población, que de facto controla la institución de dicho estado, no para ellos mismos (tener religión de estado sin otros estados a tu al rededor es como hablar en voz alta en una habitación vacía) sino para las demás comunidades. Pero entonces la religión no puede entenderse aquí bajo ninguna de las tres acepciones mencionadas, sino que de hecho tiene que ser algo que tenga que ver con mi relación con otros, o en este caso, algo que mande un mensaje a los otros lo que implica que a la definición de religión tenemos que añadir la relación de una comunidad con las otras comunidades (que por lo general ostentan otra religión). Religión son maneras, ceremonias, mentalidades, saludos, expresiones, modos, tradiciones, leyes... que se manifiestan dentro de una determinada comunidad de personas y las diferencia de otras. Si la religión hace eso, habría que preguntarse qué motivo tiene una comunidad para diferenciarse de otra, pero eso queda para más adelante.

11 Hay un verdadero debate, a mis ojos producto del uso del término "religión" en ámbitos científicos o académicos, que es precisamente lo que se critica en este trabajo. No quiere dilatar este texto con todas las definiciones pero el lector las puede encontrar fácilmente en Díez de Velasco, Breve historia de las religiones, Madrid, 2011, Alianza, cap. 1 una presentación de los debates sobre la definición. Para esta concepción, M. Elíade, Lo sagrado y lo profano, Barcelona, 2012, Paidós, 13-14.

12 En su texto clásico Lo santo, Madrid, 2012, Alianza. 
Si la religión de estado es, a parte de otras muchas cosas, la manifestación de un sector de la población que ostenta el poder afirmándose más para los demás que para fuero interno, esta faceta de la definición debería poder ayudarnos a comprender los fenómenos. Si miramos de nuevo este periodo histórico, y ahora voy a centrarme en los Uygures, deberíamos poder inteligir con más claridad lo que sucede en Asia Central en esta época. Un importante (por número o por capacidad de influencia, en cualquier caso, con poder) sector de la población debió desear afirmarse, lo que socialmente concluyó en el poder Uygur y el Maniqueísmo; este sector debía profesar la religión de Mani. En este caso, los Sogdianos, que eran la etnia sedentaria comerciante, eran los que de hecho pudieron ejercer una influencia, quizás desde el principio de la dinastía Uygur, sobre la parte nómada del Imperio. Con esta afirmación se hacía patente que quien ejercía el poder eran los Sogdianos, no los turcos Uygures, y que este estado obedecía a los intereses sedentarios, lo que se hacía patente con la construcción de una capital "sólida", sedentaria. "El estado ya no pertenece a los turcos, no somos los turcos, no somos el Tercer Imperio Turco, somos los Uygures, no somos una continuidad. Este Imperio pertenece ahora al mundo sedentario y aquí los turcos son la decoración" se dice al exterior cuando el Jaán de turno se convierte al Maniqueísmo. Así, la etnia que verdaderamente ostentaba el poder, los comerciantes Sogdianos, se manifiesta y habla a su público afirmando su identidad. Hay por tanto una idea un tanto egótica a la hora de decidirse una comunidad por una religión de estado, no muy diferente de la que hacemos todos nosotros, más cuando somos pequeños, cuando decidimos hacer o decir tal o cual cosa como una seña de identidad. Una comunidad se comporta entonces como un hombre gigante cuya cohesión y fuerza queda medida en función del deseo de cada persona por pertenecer a esa comunidad. Así, la comunidad de sevillistas o béticos se ve afirmada y fortalecida en la medida en que cada individuo desea participar de esa comunidad, y es capaz de hacer cosas por ella; al mismo tiempo, el pertenecer al Betis o al Sevilla es lo que lo definirá frente a otros colectivos. Podemos hablar de las tendencias egóticas de una comunidad por querer afirmarse en la medida en que cada persona individualmente desea pertenecer a esa comunidad. Podemos hablar de un impulso egótico que lleva a la comunidad de Sogdianos, que ostentan el poder económico, a imponerse sobre el adorno que es el poder político logrando que el estado manifieste políticamente el credo de esa comunidad, clamando en voz alta que esa comunidad tiene un credo. El título que ostenta el Jaán uigur de Zahag- $i$ Mani ("Emanación de Mani”), une la institución política y religiosa, pero es que sólo nosotros la vemos o la entendemos como instituciones diferentes. Si alguien rechaza la condición de Zahag-i Mani del Jaán uigur, está negando la constitución política y la religiosa de esa comunidad de personas, y aquí reside el problema terminológico: religión de estado es un concepto difícilmente sostenible desde la perspectiva de culturas no-europeas. En la Historia Secreta de los Mongoles, la 
familia de Temuyín se presenta como descendiente del Lobo Gris venido del cielo y la Corza Blanca ${ }^{13}$, esto es, hace que la institución quede como sacralizada: no reconocer que esta familia, la de los Mongoles, venía del cielo, era negarle la sacralidad y la legitimidad al mismo tiempo. De nuevo pregunto: ¿por qué tendríamos que separar constitución política de sacralidad?

En el caso de los Jázaros, por ejemplo, como apunta Beckwith, decir «somos judíos» significa que «no soy el perro ni de los Bizantinos ni de los Árabes», y yo ańadiría que con ello también se distanciaban de sus primos turcos de los que se habían independizado hacía poco más de un siglo (eran independientes desde el $630^{14}$ ). En el texto de Khezri publicado en Persia, cuna de civilización y cultura $^{15}$, se encuentra una narrativa (como lo es cualquier narrativa tradicional en este aspecto) con un argumento interesante sobre el origen y sentido de la revolución abbasí: un grupo de personas que están siendo tratadas injustamente por un supuesto gobierno malvado desde la lejana Damasco, deciden levantarse en armas y poner a otro grupo de personas en la institución, otro grupo de personas que sean de la familia del Profeta. El mensaje es político y religioso simultáneamente: «no sois ni justos ni sagrados, por eso yo, que sí tengo en mi mano la verdadera sacralidad, voy a poner en la institución a la persona que merece estar en la misma». Pero resulta que esta familia (los Abbasíes) traicionan a los persas ejecutando a Abú Muslim, el líder de la revolución, lo que se traduce en una serie de revueltas populares contra el gobierno de la nueva Bagdad que ellos mismos habían puesto ahí. Numerosas reacciones se producen en Persia y algunas (Estādsīs, al-Muqanna' ${ }^{16}$, Bābak Jorramdīn, Māziyār b. Qārran ${ }^{17}$ ) toman un sesgo curioso: son anti-árabes al tiempo que anti-islámicas. Finalmente, después de 200 años de insurrecciones inútiles, y bajo los Tahríes ${ }^{18}$, los Persas encuentran por fin una independencia de facto que les permita, al mismo tiempo, vivir dentro de la comunidad islámica pero con su propia personalidad. Este proceso llegará a su

13 L. Ramírez Bellerín, (ed. trad.) Historia secreta de los mongoles, Madrid, 2011, Mieaguano, $\$ 1$.

14 Beckwith, Empires... 117.

15 S. A.Khezri, "Historia de Persia", en Persia, cuana de civilización y cultura, Córdoba, 2011, Almuzara.

16 Es posíblemente el caso más interesante debido a los rasgos "comunistas" o "socialistas" de su doctrina, que Soucek relaciona con aquella de los Mazdakeos. Al-Muqanna' proponía una abolución del más estricto sunnismo, defendiendo un menor legalismo. Parece que su intención era liberar a Persia del poder Abbasí, pero no logró encontrar los suficientes apoyos. Véase S.Soucek, History of Inner Asia, Cambridge, 2000, Cambridge Univ. Press, 65-66. Sobre los Mazdakeos y su curiosa doctrina J. F. Durán Velasco, El Islam frente a las otras religiones, 2012:, Córdoba, Almuzara, 245-248.

17 Khezri, op. cit., 34-35. Cahen, op. cit., 6-88.

18 Khezri, ibíd., 36-38. Cahen, ibíd., 225-227 
perfección política bajo los Samaníes, con los cuales hay una verdadera era dorada de la nueva literatura persa ${ }^{19}$. Curioso que al tiempo que se ha desarrollado una identidad política semiindependiente o independiente de facto del poder central (en manos de los árabes extranjeros), se va desarrollando tímidamente un Islam particular, propio y lleno de influencias de la gran religión que ha dado Persia al mundo que es el Zoroastrismo ${ }^{20}$, pero que quiere justificarse ante el Islam semítico a la vez que diferenciarse de él, para lo cual, entre otras cosas, utilizará el relato clásico en el Chiísmo de que Alí recibió una enseñanza esotérica que transmitió de generación e generación a través de las figuras de los diferentes Imames ${ }^{21}$. Figuras, muy analizadas por Corbin como la de Caballería Espiritual2 ${ }^{2}$, de este tipo (que son herencia de su vieja religión) terminarán por llegar a su máxima expresión con Sohravardi, quien recuperará, ya sin ataduras o constreñimientos, la religión arcaica explícitamente y la traducirá (a veces si quiera eso) en términos islámicos ${ }^{23}$, lo que, por cierto, le costó la vida ${ }^{24}$. Lo que tras la muerte de Abú Muslim se muestra de modo violento y reaccionario en forma de revoluciones, con el tiempo acaba por aparecer de otros modos: el anti-semitismo y antiislamismo toman ahora envolturas más civilizadas pero igual de evidentes cuyo mensaje siempre es «no somos árabes, somos todos musulmanes». El Chiísmo no hace sino manifestar en el plano cultural lo que a nivel de comunidad y de política se refleja de facto, a saber, que los persas son una comunidad diferente de la comunidad de los árabes o de los semitas en conjunto. Curioso que los turcos, que por estar cerca de los persas geográficamente parece que hubieran debido de haber estado más influenciados por ellos, desarrollaron táricas ${ }^{25}$ de hecho sunníes y algunas de ellas, con cierto rigorismo (hablaremos de ellas más adelante). En el caso tibetano, por poner más ejemplos, el emperador era llamado dharmarâja ("rey religioso"26) y los monjes estaban dispuestos a su servicio, lo que Beckwith considera una continuación del concepto euroasiático del comitatus bajo la forma

19 Soucek, op. cit., 72-73.

20 Sobre la influencia del Zoroastrismo en el Islam (chií) se han escrito diferentes cosas, véase Cruz Hernandez, Historia del pensamiento en el mundo islámico I. Desde los origenes hasta el s. XII en Oriente, Madrid, 2011, Alianza, 77. En la obra de Henry Corbin hay diversos textos muy útiles y completos acerca de todos estos elementos que han sobrevivido disfrazados de Islam. Véase $\mathrm{H}$. Corbin, Cuerpo espiritual y tierra celeste, Madrid, 2006, Siruela, y Tiempo cíclico y gnosis ismaeli, Madrid, 2003, Biblioteca Nacional.

21 Véase, por ejemplo, H. Corbin, Historia de la filosofía islámica, Madrid, 2000, Trotta, 48-60.

22 En H. Corbin, El hombre y su ángel, Barcelona, 1995, Destino.

23 Corbin ha trabajado mucho el pensamiento de Sohravardi. Para ver algo sobre esta recuperación del pensamiento persa anterior véase Corbin, Historia...189-192.

24 Ibídem, 190.

25 "Tárica" es una castellanización por la que he optado ante el término árabe tarīqa.

26 "religious king" es la traducción de Beckwith (Empires, 151), pero el término dharma es más complejo de lo que puede aparentar. 
que le permitía el Budismo: en vez de señores feudales, son los monjes los que entablan una relación de lealtad con el rey, siendo éste un rey recto que vela por la comunidad. De nuevo, es difícil separar constitución política y religión: el hecho de la nueva religión no hace sino enfatizar la diferencia con el régimen anterior, al tiempo que diferenciarse de los otros regímenes que rodeaban al Tibet del momento en el siglo VIII.

\section{LA CONVERSIÓN}

Si hacemos el esfuerzo de imaginar que no tenemos por qué diferenciar religión y constitución política, costumbres, lenguaje, tradiciones, etcétera, nos daremos cuenta de que si exportamos la creencia en un Dios, poco estamos exportando: si meto a un Dios en un lenguaje, formas de vida, concepciones, que no son aquellas que constituyen la matriz desde la que ha surgido esta creencia en Dios, no estoy convirtiendo a la otra persona, sino que le estoy añadiendo un elemento nuevo que el otro asimilará desde su propio punto de vista, desde su propia matriz o paradigma. Para ser Budista no sólo es necesario rezar a Buda, sino que es necesario cambiar el paradigma, y comprender cualquier fenómeno de la realidad desde el paradigma de comprensión e interpretación que me ofrece el Budismo. Pensemos en un elemento del Budismo, como es la imagen de Buda, en otro paradigma de comprensión del mundo como es el Maniqueísmo: el resultado es que el maniqueo no asimila el paradigma del Budismo ni ve la vida ni la entiende como un budista, sino que añade a su propio paradigma un elemento nuevo que él interpreta desde su propia manera de ver las cosas. El Buda del Maniqueísmo es, efectivamente, un profeta como Jesús que ofrece una enseñanza en plena coherencia con la del nazareno ${ }^{27}$. Y realmente, la cuestión no es que ciertas doctrinas, expuestas en juicios o emisiones, puedan parecerse, sino que la concepción de fondo de una u otra difiere hasta el punto de que son contradictorias. Con esta idea de que detrás de una exposición doctrinal hay un paradigma que le sirve de matriz, o una concepción o imagen del mundo, vamos a analizar ahora más de cerca el interesante fenómeno de las (no)conversiones en Asia Central haciendo especial énfasis en dos figuras claves del (no)Islam del mundo turcófono: Ahmed Yesevi y Hacı Bektaş, y en algunas táricas sufíes y

27 Véase M. Tardieu, Le Manichéisme, París,1997, PUF, 18-25 para la exposición de la profetología de Mani, también Elíade, Historia... \$232. El Maniqueísmo estaba pensado desde el principio para formar una comunidad mundial que se extendiese por todo el mundo, lo que se tradujo en una asimilación de los distintos elementos de religioses muy diversas, esencialmente figuras icónicas como Buda, Lao-Tse o Jesús, presentando su propio trabajo como el final de toda una cadena profética. También llegó a tomar del pensamiento ajeno algunas ideas: por ejemplo del mundo hindú la idea de reencarnación, pero la cosmogonía maniquea sigue siendo una cosmogonía de una mentalidad iránia, y a poco que se lea la enseñanza de Buda o de Lao-Tse, se dará uno cuenta de que ambos personajes están muy lejos de compartir la mentalidad de Mani. 
otras prácticas religiosas ligadas al Islam en esa zona. No dejaremos de examinar otras religiones que han pasado por Asia Central para tener un número más que suficiente de ejemplos que justifiquen lo expuesto aquí. Creo que la historia de Asia Central ofrece muchos ejemplos que varían en función de la documentación que poseemos, razón por la cual hablaré más del Islam, pero de hecho, se podría hacer un estudio completo que incluyese la expansión del Zoroastrismo entre los Turcos y Sogdianos, el Maniqueísmo entre estos mismos pueblos (y también los Chinos), el Budismo en todos estos pueblos (especialmente entre los Tibetanos), el Nestorianismo y también el Islam. Tengo que matizar, para ajustarme mejor a los hechos y que no se me malinterprete, que las conversiones han existido tanto en Asia Central como en todo el mundo, pero la conversión, y es lo que pretendo demostrar, requiere el cambio de paradigma, de forma de vida. No es que no exista el Islam en Asia Central, sino que si lo hay, ha tardado mucho más en producir un efecto real de conversión y desde luego no en todas las esferas sociales (especialmente por la economía de los pueblos de Asia Central) ha sido igual.

\section{Ejemplo Primero: Zoroastrismo y Chí́smo en Sohravardi}

No quiero entrar mucho en este asunto porque hay ya una abundante bibliografía sobre él, y creo que sería redundante dedicar mucho espacio cuando la obra de Corbin, ha logrado mostrar las profundas influencias del Zoroastrismo en este pensador. Y más allá de ello, la comprensión de este autor del Chiísmo nos ha permitido ver la especificidad, ya señalada en este trabajo, irania de esta rama del Islam. En cualquier caso, si deseo señalar que en el caso de Sohravardi es muy singular el tomar conceptos zoroástricos de modo explícito: las categorías de menok y getik, y todo el orden cosmogónico de raíz mazdea de diferencias de nivel en dicho orden (sutil y pesado, que traducen menok y getik) ${ }^{28}$.

\section{Ejemplo Segundo: Nestorianismo entre los pueblos altaicos}

El Nestorianismo, se ganó adeptos por toda la estepa, siendo así que muchas tribus que más adelante jugarán un papel dentro del Imperio Mongol eran cristianas nestorianas casi por entero, lo que casi es decir que eran "religión oficial del clan" si cabe esta denominación. Los Naimanos y los Kerayitas eran nestorianos ${ }^{29}$. Los segundos están bien documentados: el cronista sirio Bar Hebreo cita una carta fechada del 1009 en el que Ebejesu, un responsable de la comunidad en Merv, escribe que convirtió a 200.000 kerayitas junto a su jaán. La carta estaba destinada a informar a Juan IV, patriarca de Bagdad (m. 1011), de estos eventos ${ }^{30}$. Posteriores narraciones dan muy buena idea de la "calidad" de estas conversiones: Guillermo

28 Cruz Hernández, op. cit., 307. También Corbin, Historia...195-197.

29 Grousset, op. cit., 190-191.

30 Ibídem, 191. 
de Rubruck ${ }^{31}$, que viajó hasta la corte del emperador Mongka Jaán, y más adelante Odorico $^{32}$, dan ambos la misma impresión de los hechos: el Cristianismo de estos pueblos apenas se puede diferenciar del paganismo que practicaban ${ }^{33}$. De hecho, los Naimanos usaban a sus monjes nestorianos como chamanes dado que podían usar poderes sobrenaturales (como controlar la lluvia) ${ }^{34}$. Esto se tradujo en la necesidad por parte de Roma de enviar a monjes que recristianizaran la zona ${ }^{35}$. De nuevo, aunque esto lo veremos más adelante con ejemplos más concretos en el Islam, donde hay mayor documentación, nos encontramos con lo siguiente: el paradigma del Cristianismo no se asimila, sino que en todo caso se asimilan elementos o figuras, pero no el paradigma completo, no el modo de pensar o el modo de ver el mundo. El monje tiene que medirse con los chamanes, hay que jugar en su terreno y mostrar a los nómadas que «nosotros los cristianos tenemos tanto poder como ellos», esto es: hay que hablar su lenguaje... Pero con ello se ha perdido el Cristianismo mismo. Para los nómadas, donde el especialista religioso es el chamán que ejerce una serie de funciones y tiene una serie de poderes, la "puerta hacia lo sagrado" se da bajo la tenencia de dichos poderes y el ejercicio de esas funciones; en el momento en el que el monje nestoriano se acerca al nómada y, para mostrarle que es más sagrado que su chamán, realiza por ejemplo una curación, o una danza para atraer la lluvia, el nómada no piensa "creo en el Señor por que me envía signos evidentes», sino que piensa «estos chamanes extranjeros tienen más poder que los míos, así que serán mejores». No me extranaraía de hecho que la figura de Jesús no se haya tomado como la de un profeta (noción que no existe en el mundo chamánico) sino como la de un gran chamán muy poderoso. De nuevo, ante el mismo fenómeno, encontramos dos marcos de comprensión muy diferentes para entenderlo porque en el fondo son dos formas de vida, dos maneras de entender el mundo o dos paradigmas, totalmente diferentes.

\section{Ejemplo tercero: Ahmed Yesevi}

Estudiemos las características de Yesevi. Éste $(\mathrm{m} .1166)^{36}$, por lo que sabemos de la narrativa tradicional y oral (cuyas fuentes trabajan Köprölü y Mélikoff) que

31 Sobre el viaje de Rubruck, ibídem, 276-282.

32 Sobre el viaje de Odorico, ibídem, 313-318.

33 Ibídem, 315.

34 Ibídem, 190.

35 Hay mucha documentación sobre viajes de estos monjes y eclesiásticos que o bien se dedicaron a las conversiones y reconversiones o bien a la administración de las iglesias desde los arzobispados. Sobre la historia del Catolicismo en China en época de la dinastía mongol, ibídem, 313-319.

36 Popovic, A./ Veinstein, G., Las sendas de Allah, Barcelona, 2007, Bellaterra, 63. D. Deweese, "The Masha'ikh-i Turk and the Khojagan: retihnking the links bewen the Yasavi and Naqshbandi sufi traditions", Journal of Islamic Studies [(1996) 183; "Foreword" en Köprölü (2006), xvii, pone en duda la cronología tradicional que manejan Köprölü y todos sus herederos (Mélikoff y Yaşar Ocak esencialmente). 
es la que nos interesa ahora, tenía una indumentaria un tanto extrańa que parecía tener una fijación obsesiva sobre los pájaros: no es que solo llevase plumas en su gorro y su capa, sino que además se le atribuye la capacidad de volar ${ }^{37}$, cosa que es harto extraña, al menos sin el concurso divino, dentro del contexto del mundo islámico; también pendían de su indumentaria amuletos y objetos metálicos del estilo de una campana ${ }^{38}$, cosa que tampoco es muy habitual dentro de la tradición de los maestros sufíes (al menos los más conocidos). Pero no es todo: de hecho Yesevi puede mover montańas ${ }^{39}$, resucitar a muertos y transformarse en una grulla $^{40}$ (hablando de grullas: cabe decir que algunos alevíes de Turquía tienen danzas tradicionales en las que se imita la forma de este animal cuando extiende las alas, danzas parecidas parece que se ejecutaban durante la zicra de su tárica, yeseviya), además, cosa extraña, se rumorea sobre su persona la presencia de mujeres en los ritos de zicra mezclada con los hombres ${ }^{41}$ (lo que en la ortodoxia es impensable) y realizaban sacrificios de buey ${ }^{42}$. Cabría mencionar más elementos, pero con esto nos es suficiente por ahora. Podemos ahora encontrar precisamente en toda la simbología chamánica turco-mongola estos elementos: el chamán puede volar y ascender a los cielos, por ello viste representando eso mismo, las plumas de diferentes aves. De hecho de ambos se dice que pueden volar, lo que es una actividad propia de los chamanes ${ }^{43}$ hasta el punto de que el primer chamán descendió al mundo en forma de águila ${ }^{44}$. La indumentaria descrita, junto con el resto de los atributos, son fácilmente reconocibles en el mundo chamánico ${ }^{45}$, incluyendo la curación y la resurrección: precisamente uno de los papeles (si no

37 Véase M. F. Köprölü, Influence du Chamanisme Turco-Mongol sur les Ordres Mystiques Musulmans, Istanbul, 1929, Mémoirs de l'Institut du Turcologie de l'Université de Stamboul, 9; Early Mystics in Turkish Literature, London-New York, 2006, Routledge, 23; I. Mélikoff, "From God of Heaven to King of Men: popular Islam among turkic tribes from Central Asia to Anatolia", Religion, Stade and Society, vol. 24, nos. 2/3, 1996, 134-138.

38 Ibídem.

39 Yesevi destruye una montańa siendo un niño a causa del descontento que dicha montaña le produjo al jefe turco de turno llamado Yesevi y por el cual se ganó el nombre de "Yesevi" el proopio Ahmed. Lo que se narra es que hizo desaparecer la montaña. Köprölü, Early...22.

40 Köprölü, ibídem 23. Mélikoff, op. cit., 134.

41 Köprölü, Influence... 7; Early... 24. Las fuentes de Köprölü mencionan que sobre Ahmed Yesevi corrían rumores de que incumplía la Ley Islámica, pero parece solucionarlo todo siempre con algún milagro y se dan cuenta de que es mentira, que no incumple la Sharia. De hecho Köprölü, ibídem,106, se enorgullece de que Yesevi sea así de puro frente a los iraníes por ejemplo (posiblemente tenga en mente a Sohravardi, que como hemos visto mantenía muchos elementos iranios). Aun así, la presencia misma de tales rumores es significativa.

42 Ibídem, 8-9.

43 Elíade, Historia...\$246.

44 Ibídem. Aunque hay varias interpretaciones sobre la intervención de la figura del águila según la tradición concreta, véase Elíade, El chamanismo, 72-44.

45 Elíade, ibídem, cap. V, dedica mucho tiempo a describir con detalle la indumentaria y el simbolismo con todas las varientes a su alcance según pudo documentarse. 
el más importante) del chamán es curar ${ }^{46}$. Köprölü afirma que la transformación en pájaros puede tener un origen budista ${ }^{47}$, pero lo cierto es que es más sencillo entenderlo, como hace Mélikoff, desde el punto de vista puramente chamánico. Especialmente, en el caso del pájaro, es un símbolo demasiado universal como para que Köprölü quiera verlo como una influencia unívoca del Budismo o de alguna corriente hindú: el símbolo del pájaro está demasiado presente en muchas religiones como para realizar semejante afirmación. Entenderlos como Mélikoff como pervivencia del Chamanismo, repito, me parece más lógico. En cualquier caso, conscientes de que estamos siguiendo la narrativa tradicional, no dejan de ser llamativos los elementos que vemos aparecer, elementos que vienen a explicar por qué triunfó a nivel popular o más bien como el pueblo comprendió la figura histórica de Yesevi: presentaba atributos que el pueblo podía entender, y al mismo tiempo se generan desde una concepción de lo sagrado determinada: a Yesevi se lo puede entender como puerta a lo sagrado porque ostenta unos atributos y realiza una serie de funciones, y al tiempo él mismo puede entenderse como justificado o con voz para hablar de lo sagrado porque ostenta esos símbolos y realiza esos milagros. El pueblo comprendió (o al menos desde los documentos que trabaja Köprölü) la figura histórica de Yesevi de ese modo. Tomemos el ejemplo del pájaro: no es que elemento chamánico haya permanecido dentro del Islam, es que hablamos de una mentalidad: aquella que concibe que el cielo es el mismo Dios y que hablar con lo sagrado requiere de alguien que sea capaz de volver, esto es, de ascender a los cielos. Dios no se aparece y habla a los chamanes como sucede con los profetas, sino que los chamanes tienen que visitar a los Dioses y allí hablar con ellos, mandando peticiones de la comunidad y trayendo mensajes de los Dioses después. Pero esta concepción difiere totalmente de aquella semítica. Este mismo fenómeno se puede aplicar también al éxito del Budismo, en su variante tibetana, entre los Mongoles: parece que la magia ejecutada por sus monjes causó un sensacional éxito entre los mongoles, lo que podría verse de nuevo como la aplicación del mismo esquema que hemos desarrollado aquí con Yesevi. Esto podría llevarnos a pensar, como anota David O. Morgan ${ }^{48}$, si no serían los elementos pervivientes del propio chamanismo tibetano pre-budista el que atrajo la atención de los Mongoles que se decidieran a practicar el Budismo.

46 Ibídem, 154-156.

47 Köprölü afirma que puede ser una perviviencia del Budismo en la zona del Turkestán Chino dado que la transformación en pájaro es un tema del folklore hindú. Esta conexión la fundamenta o refuerza con la idea de que muchas tumbas de santos musulmanes en el Jotán (en el Turkestán Chino) pertenecían a viejos conventos budistas, además expone otro elemento de posible origen budista como puede ser el hacer que sus enemigos se transformen en animales [Köprölü, Influence...9-10].

48 D. O. Morgan, Los Mongoles, Madrid,1990, Alianza, 150. 


\section{Ejemplo cuarto: Haci BeKtaş}

Este santo comparte muchas características (de nuevo desde la óptica de la narrativa tradicional) con nuestro ya conocido Yesevi: mueve montańas, resucita a muertos (resucitó a un niño en un poblado mongol $^{49}$ ), adopta forma de pájaro, vuela... Pero quiero ahora señalar algunos detalles que parecen ser propiamente suyos, concretamente dos: $1^{\circ}$, el rezo en las montañas; $2^{\circ}$, el uso del ardıç (variedad asiática del enebro). Parece que Hacı Bektaş no tenía especial interés en ir a rezar a las mezquitas ${ }^{50}$, en cambio gustaba de ir a realizar sus oraciones a las montañas ${ }^{51}$, donde, por cierto, crece esta variedad de enebro mencionada, el ardiç ${ }^{52}$; ahora quizás sea preciso mencionar que esta variedad de enebro provoca alucinaciones si es quemada y aspirado el humo resultante (también el fruto y las hojas parecen provocar un efecto de la misma especie en desigual intensidad). El uso del ardıç parece extendido entre el monacato tibetano (observando el mismo ritual de quema y aspiración del humo producido), y también entre chamanes pakistaníes (éste último toma sus frutos y mastica sus hojas antes de entrar en trance) ${ }^{53}$. El uso de este enebro está por tanto no solo conectado con el chamanismo propiamente altaico (turco-mongol) sino que podría estar ligado, dado la localización del sitio donde parece usarse, a la religión tibetana prebudista: el Bön. Otros usos clásicos del chamanismo, como es el entrar en éxtasis mediante el uso del tambor cuando se va a realizar algún ritual parece también heredado del chamanismo ${ }^{54}$ : gracias a la zicra ${ }^{55}$ sonora usada por algunos de estos sufíes, realizan el mismo rito sustituyendo el tambor con la melodía provocada por la zicra (a lo que podemos añadir el uso de los estupefacientes mencionados para acentuar el estado de trance propio del chamán). Con respecto al culto de las montańas como lugar sagrado en lugar de las mezquitas, la respuesta no está estrictamente en una costumbre chamánica, sino más bien en una creencia o doctrina de la religión que comparten turcos y mongoles: la del Dios del cielo Tanrı. Éste es el Dios creador del mundo,

49 Mélikoff, op. cit., 134.

50 Como anécdota ilustradora de la pervivencia de estas maneras en la actualidad, en la estepa central de Anatolia conocí a un turco aleví que me dijo literalmente: «mescide köpekler» («a la mezquita [van] los perros»).

51 Ibídem.

52 Ibídem.

53 Ibídem

54 Sobre las diversas variantes del ritual chamánico, así como los diversos ritos, véase Elíade, El chamanismo... En esta obra se encontraron descritos numerosos ritos dentro de los diferentes pueblos con prácticas chamánicas. Posiblemente, los ritos de ascención, los de iniciación, los viajes celestes y los de descenso sean los más importantes. Para un resumen más breve, véase del mismo autor, Historia... $\$ 246$.

$55 \mathrm{La}$ "zicra" (en árabe, literalmente, "recuerdo") es un acto comunitario en el cual lo musulmanes se reunen para "recordar" a Dios recitando el Corán de forma melódica. Las sesiones de zicra más grandes (dependiendo de la tárica harán diferentes cosas, pero la estructura suele ser igual) se incluye una suerte de danza en la que se repite, entre otras cosas, el nombre de Dios. 
y su morada es todo el cielo, de hecho él es el cielo ${ }^{56}$. El problema es que en tanto que el mundo de lo sagrado está totalmente ligado a algo que es inalcanzable (al menos si no cuentas con un chamán que puede establecer contacto con el cielo ascendiendo a él con sus poderes) y que no toca si quiera el mundo en el que uno se maneja, introducirse en lo sagrado resulta un problema: para un musulmán, entrar en una mezquita es cruzar la línea entre lo sagrado y lo profano (por ello de hecho exige una purificación representada por las abluciones realizadas antes de pisar la mezquita). Pero no parece que los que profesaban religiones altaicas tuvieran la sensación de que hubiera "espacios privilegiados" como la mezquita o la iglesia, toda la tierra era homogénea ${ }^{57}$ : Chenguis Jaán le dice al Imam de Bujara «el universo entero es la casa de Dios, ‘a qué viene señalar un lugar especial, la Meca por ejemplo, para acudir a ella?58". Pero ante la necesidad de establecer un punto de contacto, se recurre a lo más cercano que puede haber para unirse al cielo: la montańa que se eleva por encima de las estepas ${ }^{59}$. Las montañas de hecho son hasta tal punto sagradas que se las llega a adorar como si estuviesen vivas y pudiesen cambiar ellas mismas el curso de los acontecimientos, como sucede de hecho en el caso del propio Chenguis Jaán, cuando, según nos narra la Historia Secreta de los Mongoles, el joven Temuyín promete adoracón a una montaña. Huyendo el clan rival de los Merkit, considera que el monte Burján ${ }^{60}$ le ha salvado la vida y promete ofrecerle plegarias: «[...] y el monte Burqan, ocultándome, ha salvado mi efímera vida. De ahora en adelante habré de adorarlo por siempre, y también habrán de adorarlo los hijos de mis hijos y los nietos de mis nietos ${ }^{61}{ }$. Ahora podemos entender a Bektaş y su general desprecio a las mezquitas: en la montańa está más cerca, literalmente, del cielo (tanr $)$. Estas dos cosas mencionadas, el uso del ardiç por un lado como la adoración en la montaña, no son elementos, sino que son maneras de entender mi relación con lo sagrado. Yo podría entender la vestimenta, por ejemplo, como la pervivencia de un elemento, pero difícilmente podría decirse lo mismo del uso de narcóticos y del rezo en las montańas, ambas cosas son una manera de relacionarme y de entender lo sagrado y lo profano. Un musulmán no ve una montaña y la considera sagrado, pero un aleví, al menos por aquellos tiempos, sí lo hace (y muchos lo seguirán haciendo). No es, repito, un elemento, esto es una manifestación de una forma de pensar.

56 Tanto en turco como en mongol "cielo" y "dios" se siguen diciendo tanr.

57 Ibídem, 135.

58 Elíade, Historia, $\$ 242$.

59 Mélikoff, op. cit., 135

60 En edición citada se verá escrito Burqan, pero de hecho esa "q" equivale a la jota española y por ello escribo castellanizado Burján, respetando en la cita "Burqan".

61 Ramírez Bellerín, Historia...\$103 
AClarar El FENÓMENo de LA CONVERSión

Después de todos los ejemplos mencionados (sólo unos pocos con todos los que se podrían mencionar de Asia Central), creo que podemos afirmar que no existe conversión a no ser que haya un cambio de la constitución politica y social de una comunidad, asi como de paradigma (de modo de pensar o forma de vida). Una conversión no puede ser individual, al menos en un sentido serio: la religión es algo que, como el lenguaje, se comparte con una comunidad que viva todas esas mismas creencias, ritos, pensamientos etcétera. Si uno se convierte al Islam pero sigue pensando y entendiendo las mismas cosas que hacía antes, cambiando lo que antes llamaba Tanr por Allah, poco ha hecho, incluso aunque rece con la forma en la que lo hace un musulmán, incluso aunque vaya a la mezquita, el paradigma no cambia, sino que se cambian nombres y maneras superficiales. Para convertir a una persona, lo más importante, es incluirla en la nueva comunidad a la que va a pertenecer, para que hable, piense, se mueva y se ate los cordones de los zapatos dentro del marco/ matriz/ paradigma que le ofrece la comunidad. Tenemos en Asia Central una nutrida e interesante historia de las religiones porque lo que tenemos es en realidad la historia de una serie de mentalidades que, como los estados, chocaron y se impusieron simultáneamente unos sobre otros con el mismo grado de confusión que con las religiones: sin entenderse realmente entre ellos. Así, pues tenemos supuestos monjes cristianos que hacían la danza de la lluvia para convocar esta fuerza de la naturaleza, o musulmanes que se dedican a fumar alguna variedad de enebro para alcanzar éxtasis espirituales. Añadir un número de elementos propios a un paradigma extraño no genera ninguna masa crítica que termine desplazando un paradigma, sino que lo único que puede hacer real un cambio de paradigma es la inmersión de una persona en la comunidad de "hablantes" de esa religión. No soy musulmán cuando rezo a Allah cinco veces al día sino cuando soy capaz de interpretar un fenómeno de la vida cotidiana desde el paradigma "semítico" en su versión musulmana. Si yo interpreto la muerte de mi madre y siento y padezco dicho fenómeno en clave de "Dios está realizando su plan divino y esta muerte aunque me duela es buena”, yo puedo decir que soy Budista que es una soberana mentira. Del mismo modo, uno pertenece al Islam cuando hace determinadas preguntas o se plantea ciertos problemas de una determinada forma y no de otra. Cuando uno en su vida se plantea las cosas de una manera, esa manera es su paradigma o surge, mejor dicho, de su paradigma, que se mantiene gracias a los padres, los amigos, los profesores y un largo etcétera que se resume con la palabra comunidad. Si volvemos a Asia Central, podemos entender que en las ciudades era más sencillo un cambio de paradigma que en el mundo nómada no por una cuestión de creencias, sino porque el Islam tiene una mentalidad mercantil que podía cuajar mejor en las ciudades que en la estepa, donde hay un modo de vida, una comunidad y una mentalidad con ello diferentes. 
PARTe II.

SOLUCIONES Y CONCLUSIONES

Hemos hablado bastante de la conversión y de religión como religión de estado desde Asia Central, y ahora creo que estamos en posición de hacer algunas afirmaciones con respecto a la definición misma de religión.

Señalaba Freud, tanto en Totem y tabú como en Moisés y la religión monoteísta, que al final tanto la religión como el estado nacen al mismo tiempo y son completamente indiferenciables: cuando los hombres (sólo los hombres) realizaban el pacto, instituían al mismo tiempo las "leyes" (prohibición del incesto y observación de la exogamia), el rito, la creencia, las costumbres, y en definitiva, la cultura entera ${ }^{62}$, cosa con la que concuerda perfectamente LéviStrauss ${ }^{63}$. Si pensamos en lo que significa "cultura" en ese momento, nos daremos cuenta de que difícilmente podríamos discernir en ella lo puramente político de lo puramente religioso de lo puramente artístico etcétera. Durkheim, con su monumental Las formas elementales de la vida religiosa, viene exponer una idea de la que Freud no es más que la natural continuación, a saber, que todos los conceptos religiosos provienen, se forman y tienen sentido dentro de un colectivo, siendo imposible concebirlos fuera de la colectividad ${ }^{64}$, es más, es que la religión o el culto son el grupo mismo hipostasiado, la colectividad hecha representación, de modo que realizando el culto religioso uno en realidad está haciéndole culto a la propia comunidad ${ }^{65}$. Durkheim además se toma la molestia de hacer una relación de todos los cultos que recolectando de los aborígenes australianos explicando que todos esos cultos se entienden desde el concepto de comunidad ${ }^{66}$. Una labor parecida puede realizarse en otras comunidades (nómadas turcomongoles, semitas, europeos), y la conclusión será probablemente la misma a la ya Durkheim llegó: la religión es cosa de la comunidad, es más, forma una parte indiferenciable de la misma. El acto "político" del juramento de lealtad de unos hombres a otros se reviste simultáneamente de un carácter sagrado, siendo lo normal que cuando se el hombre jura en el más alto sentido de la palabra, lo hace por lo general en el nombre de Dios; ahora bien, jurar en nombre de Dios no es

62 S. Freud, Totem y tabú, Madrid, 2012, Alianza, 186-187; Moisés y la religión monoteista, Madrid, 2010, Alianza, 146.

63 C. Pateman, El contrato sexual, Barcelona, 1995, Anthopos, 155-156.

64 Efectivamente, lo que tiene poder activo sobre el individuo es el culto, es decir, la realización de un rito en una comunidad, como es el caso de la zicra, por poner un ejemplo, entre los musulmanes. Véase Durkheim, Las formas elementales de la vida religiosa, Madrid, 2008, Alianza, 628-630.

65 Ibídem, 633, 635.

66 Véase de esta obra el lib. III, con sus cinco capítulos a explicar todos los tipos de rito. 
sino enfatizar que esa palabra dada tiene el más alto grado de compromiso con el resto de la comunidad que cualquier otro tipo de promesa, no significa nada más, ni nada menos. El acto del contrato, la promesa, el compromiso o del pacto no tiene más valor político-social que religioso. A ese "magma" indiferenciado que puede llamarse desde "cultura" hasta "costumbres" o "maneras de vivir" es a lo que habría que hacer referencia, y no a un único aspecto que nos deja con una visión un tanto sesgada y pobre del fenómeno. Todo esto sería perfectamente inteligible si no fuera por el fenómeno de las religiones con vocación misionera: el Budismo, el Zoroastrismo y las religiones abrahámicas. Son las únicas que históricamente han buscado la conversión de otros pueblos. Al hacerlo, han generado un problema a la hora de comprender el fenómeno religioso: porque sin desearlo expresamente, se han visto obligados a separar aspectos de su cultura para implantarlas artificialmente en otras, generando una interesante historia de movimientos de ideas religiosas que en último término no es sino la historia de unas culturas que no se entendieron ni se entenderán. Para inteligir ese fenómeno he expuesto anteriormente la idea de elementos aislados que se extraen de una cultura para ponerse sobre otra cultura, sin que el paradigma de comprensión de ambas, en sentido fuerte, cambie. No creo, añado, que esté diciendo nada nuevo sino que estoy enfatizando aspectos de cosas que están más que dichas, solo creo estar poniendo en orden muchas ideas de distintos autores.

\section{Conceptos (I): COMUnidad}

Antes de pasar a exponer el fenómeno de la conversión y del proselitismo, me veo forzado a exponer con detenimiento esos conceptos de comunidad, cultura, paradigma, que he usado quizás muy gratuitamente. Entiendo que se habla de COMUNIDAD cuando un grupo de personas actúan buscando un bien que no recae directamente sobre ellos sino que recae sobre ellos pero también sobre todos los demás. Este bien común que buscan un grupo de personas es lo que se designa como común-idad, pero que expresa mejor common-wealth (bienestar común). Esta comunidad es fuerte o cohesionada en la medida en que sus miembros estén dispuestos a dar algo por ella. La pertenencia a dicha comunidad puede ser puesta en entredicho si un supuesto miembro resulta que no da nada por ella. La medida en que los miembros se sienten tales dentro de la comunidad es la medida de su fortaleza. Si esta comunidad tiene o no instituciones es irrelevante, dado que la obediencia a las instituciones viene al final determinada por el grado en que se cree en que dichas instituciones representan fielmente a la comunidad, pero no aporta nada a la definición el que haya instituciones o no. Los dos grandes autores del contrato, Hobbes y Locke, han dado la clave para entender las comunidades sociales, por ello me voy a detenerme a defender lo que yo creo que se puede salvar de sus respectivos pensamientos en lo que se refiere a las sociedades. Yo interpreto su pensamiento de modo sincrónico y no diacrónico, es decir, no leo 
en sus textos la exposición histórica de cómo unas comunidades pasaron de un estado de naturaleza a un estado social (en diacronía) sino que leo cómo de hecho se ha de comprender el sentido de las instituciones políticas, cómo funcionan, su sentido (en sincronía). Yo no tengo documentos para pensar que hubo un pacto social, pero sí entiendo que la sociedad tiene un objetivo y un fin y entiendo el gobierno como atendiendo a ese fin. Las sociedades están para algo, tienen un sentido, aunque el pacto social no sea un hecho histórico. Hobbes y Locke difieren en cuál es el origen de la comunidad política ${ }^{67}$, pero ese supuesto origen no hace sino justificar el que el estado tenga por obligación que cumplir un fin, siendo el caso que si no lo cumple, la institución deberá responder ante el pueblo que gobierna. En el caso de Locke es muy explícito, y dedica mucho tiempo a argumentar la legitimidad de una revolución ${ }^{68}$. En la historia de Asia Central tenemos una ventaja adicional: como los pueblos turco-mongoles son nómadas, ejemplos del décimo nono capítulo del Segundo tratado sobre el Gobierno Civil se han repetido varias veces en la historia. Porque, al contrario que en Inglaterra (o Europa en general) donde la población es sedentaria y por tanto no cabe abandonar la tierra e irse a otra parte, en Asia Central, allí donde una comunidad carecía de la capacidad de mantener la cohesión de sus miembros, la comunidad se ha disuelto con naturalidad. Dice Weiers: «der Zusammenhalt solcher Gemeinschaften, welche die Geschichteswissenschaft zugegebenermaßen etwas unüberlegt schon gleich als "Reiche" oder "Staaten" zu bezeichnen pflegt, war meinst nur locker und überaus störanfällig, denn an stabilisierende Richtlinien wie etwa ausformulierte Verfassungen konnte man sich nicht halten, da es diese überhaupt nicht gab. Das Zusammenleben regelten bestenfalls Strafgesetze, die auf die jeweiligen momentanen Bedürfnisse einer Gemeinschaft hin festgesetzt wurden./ Das, was diese Gemeinschafen zum Zusammenschluss brachte, waren in erster Linie die Aussichten auf bessere Möglichkeiten für das Leben oder Überleben. Als zusätzlicher "Kit" innerhalb einer Gemeinschaft konnen dabei Identität, Tradition, Solidarität, und Effizienz eine herausragende Rolle spielen. Diese idealtypischen politischen "Bindemittel” bieten sich nun für den gesamten zentralasiatischen Raum als Kriterien an, um anstelle von Staaten oder Reichen zunächst einmal eher von Identitäts-, Traditions-, Solidaritäts-, und Effizienzgemeinschaften zu sprechen. Unbeschadet dessen konnten sich aus solchen Ur-Staat-Gemeinschaften durchaus auch Gebilde entwickeln, die man als Reiche oder Staaten bezeichnen kann ${ }^{69}$ ». Estas palabras de Weiers, que al menos

67 J. Locke, Segundo tratado sobre el gobierno civil, Madrid, 2010, Alianza, \$\$123-124, argumenta en su texto que el fin del estado es la preservación de la propiedad privada, en cambio Hobbes piensa en la propia seguridad, en la conservación de la integridad física.

68 Locke, ibídem, cap. 19.

69 M. Weiers, Geschichte der Mongolen, Stuttgart, 2004, Kohlhammer, 20. Traducción (mía): «La cohesión de semejantes comunidades, de las cuales la ciencia histórica, algo ireflexiva, abiertamente 
para la historia de Asia Central inclinarían la balanza en favor de los autores contractualistas (con muchos matices ${ }^{70}$ ), son muy reveladoras: una comunidad se une con un objetivo, que es la mejor calidad de su existencia (como en el caso de las Effizienz-gemeinschaft o las Solidarität-gemainschaft). Cuando el objetivo que se tenía se pierde en el horizonte, la comunidad se disuelve. Quizás es este uno de los motivos por los que las comunidades nómadas han sido más abiertas y tolerantes (e igualitarias) que las comunidades sedentarias: si no hay una idea de "estado" o "reino" fija, no hay símbolos fuertes ni identidad fuerte, sino que se tiene una mentalidad más capacitada para comprender a los otros y aceptar al otro ${ }^{71}$. En cualquier caso, esta idea de comunidad es la que mantengo: sólo hay comunidad cuando hay un objetivo muy claro. Y considero que la comunidad es débil o está decrépita cuando sus miembros pertenecen a ella por inercia. Esto sucede en las comunidades sedentarias, esencialmente, porque su economía no le permite, en caso de disolución de la comunidad, abandonar la comunidad físicamente, de modo que un campesino británico (y en general, todos los sedentarios) no tiene opción de marcharse si está descontento con su gobierno porque su tierra no puede marcharse con él. Conocemos la clave de la vida en comunidad cuando la comunidad no tiene ni proyecto ni sentido: resignación y aburrimiento. Una comunidad es débil, carece de cohesión social, cuando sus miembros no ven delante de sí el sentido de su unión. Y en ese caso, los símbolos que usará el estado serán igual de vistos que los mismos objetivos de la comunidad.

\section{Conceptos (II): CUlTURA Y PARAdIGMA}

Entiendo por CULTURA todo aquello que se suma a la naturaleza biológica del hombre, y aquí sigo enteramente a Freud en su El malestar en la cultura, esto es, desde el lenguaje hasta los aperos del campo, al arte, o el calzado. Siguiendo su definición: "suma de las producciones e instituciones que distancian nuestra

tiene a bien designar como "reino" o "estado", era más algo laxo y propenso a las interferncias que una [comunidad] estable y lineal, dado sobre todo que una costitución formulada no se podía mantener. Esa vida en común estaba regida en el mejor de los casos por una ley marcial o criminal que de la particular necesidad momentánea arreglaría o uniría una comunidad./ Lo que traían estas comunidades para su fusión eran en primer lugar las vistas a mejores posibilidades de vivir o sobrevivir. Así, adicionalmente, también podían jugar un papel preponderante en el "kitt" interno de la comunidad la identidad, la tradición, solidaridad o la eficiencia. Estos ideales y típicos medios de vendaje político se ofrecen ahora para la totalidad del espacio centroasiático como criterio para, en vez de estados o reinos, hablar en primer lugar de comunidades por identidad, por solidaridad, por tradición o eficiencia. Al margen de esto podían también estos proto-comunidades-estado absolutamente desarrollar formaciones que pueden ser designadas como reinos o estados».

70 No podemos concebir, por ejemplo, un estado de naturaleza en el que los individuos vivan aislados.

71 Lo que podría explicar también por qué los nómadas se han asimilado siempre a las poblaciones conquistadas cuando éstas han sido esencialmente sedentarias. 
vida de la de nuestros ancestros animales y que sirven para dos fines: proteger al hombre contra la naturaleza y regular las relaciones de los hombres entre $s^{172}$ ». En el campo de las "producciones" incluyo también aquellas cosas estrictamente no materiales como mi lenguaje o mi forma de ver el mundo, mi manera de interpretarlo, que es de lo que paso a hablar ahora y que designo con el término PARADIGMA, por lo que concibo algo complejo que ni yo mismo tengo del todo claro, aunque la idea proviene abiertamente de Kuhn en La estructura de las revoluciones científicas, no sin influencia del concepto de "forma de vida/ juego del lenguaje" del Wittgenstein de las Investigaciones filosóficas. El uso del término en este campo es, creo, la única novedad que hay en este escrito, y que he usado yo mismo para clarificar los movimientos religiosos en Asia Central, para comprenderlos mejor. Wittgenstein, de hecho (así lo señala Echeverría ${ }^{73}$ ), ya había usado paradigma en el contexto de teoría del ciencia en sus Investigaciones filosóficas. Como una definición suficiente de paradigma, podríamos decir con las palabras de Kuhn: «un paradigma es un modelo o patrón aceptado ${ }^{74}$ ", que origina una serie de creencias y hábitos ${ }^{75}$. Echeverría clasifica los distintos sentidos del término paradigma, que es harto problemático en Kuhn, en tres sentidos fundamentales ${ }^{76}$ de los cuales nos interesa esencialmente el primero, el aspecto filosófico o metafísico, a saber, la imagen del mundo o las creencias básicas de una comunidad de científicos. Precisamos un poco, para ver matices sociológicos que nos interesan mucho, volviendo a citar a Kuhn: «un paradigma es aquello que los miembros de una comunidad científica, y sólo ellos, comparten y a la inversa, es la posesión de un paradigma común lo que constituye a un grupo de personas en una comunidad científica, grupo que de otro modo estaría formado por miembros inconexos ${ }^{77}$ ». Tenemos dos matices: uno sociológico (un paradigma se comparte por una comunidad y la definición de pertenencia a esa comunidad se realiza en términos de compartir ese paradigma) y el otro "filosófico/ metafísico", a saber, que es el conjunto de creencias, por decirlo así. Para matizar esto último introduzco ahora unos conceptos del segundo Wittgenstein: Bild, Auffasung, Vorstellung, que se confunden en su obra o se usan casi como sinónimos. Baker ha descrito bien el alcance de estas nociones: «a picture [Bild] gives no information, hence, no incorrect information [...] Perhaps it is more like a way of seeing things, a conception (Auffasung), or a norm of representation. Its adoption may force us to give descriptions having a particular pattern ${ }^{78}$. Weiers ha denunciado esto

72 Freud, El malestar de la cultura, Madrid, 2011, Alianza, 88.

73 J. Echeverría, Introducción a la metodología de la ciencia, Madrid,1999, Cátedra. 115.

74 T. S. Kuhn, La estructura de las revoluciones cientificas, México, 2012, FCE, 88.

75 Echeverría, op. cit., 116.

76 Ibídem, 116-117.

77 Kuhn en Echeverría, 117

78 G.. Baker, "Wittgenstein: concepts or conceptions?, The Harvard Review of Philosophy 
mismo, como veíamos en el epígrafe anterior: nuestra concepción de estado nos hace usar patrones de descripción que no cuadran para las comunidades nómadas de Asia Central, haciendo que "estado" o "reino" puedan eventualmente llevarnos a equívocos o distorsionar la realidad y la comprensión de los fenómenos históricos; "estado" o "reino" proceden y designan cosas desde nuestro modo de ver las cosas, no desde $s u$ modo de ver las cosas. Quiero poner un ejemplo que nos permita visualizar de modo más redondo de qué modo nos afectan los paradigmas o maneras de ver las cosas. Q. Skinner, defendiendo a Berlin en su artículo «a thirth concept of liberty ${ }^{79}$ " ante los ataques de MacCallum, afirma que sería pervertir o malinterpretar el concepto de libertad que tiene Berlin si se lo interpreta desde la concepción de la libertad como la relación triádica que defiende MacCallum, porque ambas definiciones de libertad difieren en su concepción: «what underlies these theories of positive liberty is the belief that human nature has an essence, and that we are free if and only if we succeed in realising that essence in our lives. This enables us to see that there will be as many different interpretations of positive liberty as there are different views about the moral character of humandkind ${ }^{80}{ }$. Mi definición de libertad depende de unas serie de creencias previas (el paradigma) que me determinan a expresar una serie de conceptos de una determinada manera, no de una visión "desnuda". Skinner después de esta frase pone varios ejemplos de concepciones diferentes de la naturaleza humana que nos pueden servir para ilustrar como dichas concepciones definen la gramática en la que yo podré expresar mi definición de libertad. Bocardo (2013) señala dos aspectos importantes dentro de esta idea de Auffasungen o Bild que deseo señalar aquí, la primera es que «entendidas como "maneras de mirar, o de considerar las cosas" las representaciones se convierten en una norma o forma de representación [...] y como tales determinan la gramática de los conceptos, es decir, establecen un cierto patrón con arreglo al cual se establece el uso de los conceptos ${ }^{81}{ }$. El segundo aspecto que resalta Bocardo es que al ver el mundo mediante estas concepciones o "imágenes" (picture, Bild), nos cegamos inmediatamente a ver otros aspectos del mismo que quedan fuera de los que nosotros, literalmente, podemos concebir ${ }^{82}$.

IX. 2001, 10: «una imagen [Bild] no da información alguna, y por ella, información incorrecta alguna [...] Quizás es más como una manera de ver las cosas, una concepción, o una norma de representación. Su adopción puede forzarnos a dar descripciones teniendo un patrón particular». Traducción mía.

79 Q. Skinner, "A Thirth Concept of Liberty", Proceeding of the British Academy, 177, 2002.

80 Ibídem, 242. "Lo que subyace a estas teorías acerca de la libertad positiva es la creencia de que la naturaleza humana tiene una esencia, y que somos libre si y sólo sí logramos darnos cuenta de dicha esencia en nuestras vidas. Esto nos permite ver que habrá tantas interpretaciones de la libertad positiva como viosones acerca del carácter moral del ser humano». Traducción mía.

81 E. Bocardo, "El dogma de las intenciones ilocutivas", en Oncina Coves, F. (ed.), Tradición e innovación en la historia intelectual. Métodos historiográficos, Madrid, 2013, Biblioteca Nueva, 154.

82 Ibídem. 
Así, en mi manera de comprender el mundo en un sentido amplio yo puedo interpretar hechos de mi vida cotidiana de una manera y plantear problemas de una manera que desde otra forma de vida no tiene ningún sentido. Así pues, en un paradigma "semítico" la pregunta por la ausencia de Dios es impensable. Puede haber uno o veinte Dioses, puede haber malos y buenos, pero no un mundo sin Dioses, y no desde luego un mundo que sea igual a Dios. Las diferentes respuestas a los problemas que nos deja plantearnos una determinada concepción de una cultura se nos ofrece en la variedad de sus vertientes: el Maniqueísmo, el Cristianismo o el Islam son respuestas diferentes a los problemas que esa cultura se plantea desde su paradigma, pero, remarco esta idea, todas estas respuestas están dentro del mismo paradigma y de hecho es lo que hace que estas religiones puedan entenderse y, a la vez, odiarse mutuamente. Un budista y un musulmán no se odian, sino que no se entienden: todo el Budismo parte de la premisa de que la existencia es intrínsecamente sufrimiento, y la mayoría de los problemas que se plantean en su seno son acerca de cómo aliviarse uno del mal que es la existencia, pero el sufrimiento es un problema que para el musulmán es inconcebible porque el mundo lo ha creado necesariamente un Dios bueno, así que el sufrimiento se interpreta como un trámite, como una prueba o incluso como un acto deliberado de maldad, pero cualquier caso tiene un sentido porque ese acto se enmarca dentro de una voluntad suprahumana, dentro de una teodicea de uno u otro carácter. De modo que no hay diálogo posible entre estas religiones: no hay un marco de interpretación común, no hay una imagen del mundo común. Un cristiano y un musulmán se pueden entender porque hablan "dialectos de la misma lengua", pero un budista y un cristiano no pueden entenderse porque no hablan el mismo idioma, esto es, no entienden el mundo de la misma manera.

\section{Conceptos (III): ELEMENTO}

Por último, entiendo por ELEMENTO objetos particulares de esa forma de vida, y no la forma misma. Un elemento puede ser un tipo rezo, una ley, una prescripción, una costumbre. Un elemento y un paradigma se relacionan de la misma manera que una gramática y un vocabulario. Así, para concebir las relaciones interculturales, pongo el siguiente ejemplo: pongamos por caso que sustituyo satisfactoriamente todos y cada uno de los sustantivos en castellano que vienen del latín por sustantivos que vienen del árabe, ¿podríamos considerar con ello que el castellano bajo esas circunstancias fuese una lengua semítica?. Imposible, porque la gramática con la que un hispanohablante se expresaría seguiría siendo castellana, aunque yo haya importado del árabe todos los sustantivos que yo quiera.

En resumen: comunidad (commonwealth), paradigma y cultura pueden concebirse entonces de modo compacto y unido. La variedad dentro de un 
paradigma, y la variedad de paradigmas designa entonces simultáneamente las variedades de una misma cultura y la variedad de culturas al mismo tiempo que la variedad de comunidades. Esta es la clave: no hay que redefinir o seguir trabajando con el concepto de religión sino suprimirlo, porque "religión" sólo genera confusiones, no designa nada claro. No hay nada religioso separado de lo comunitario o lo político. Lo que existen son comunidades que comparten una misma manera de pensar o entender el mundo, y lo que los define como comunidad es esa manera de ver el mundo. Y las comunidades, por lo general, no son conscientes de que viven presas de esa Bild o Auffasung que las define, del mismo modo que los hablantes de una lengua no conocen ni comprender la gramática de su propio idioma. Es pervertir o malinterpretar a todas las demás comunidades pensar que concibieron algo así como una religión separada de su institución política como pueblo. Pongo dos ejemplos: uno del hebreo (beytkeneset) y otro del árabe (din). Beyt-keneset en hebreo se traduce como sinagoga y lo que traemos a la mente es un lugar "religioso", signifique esto lo que signifique, pero de hecho beyt-keneset significa literalmente casa de la reunión. Un hebreo no piensa que ellos sean practicantes de una religión, piensan que son miembros de una comunidad, y una de las instituciones, la más importante, de dicha comunidad es la casa de la reunión, pero no es un edificio religioso: ¿cómo iba a ser un edificio religioso el edificio donde se enseña la ley y donde se enseña a aplicarla?, y aun así seguiríamos viendo una sinagoga como una institución religiosa y no comunitaria porque nosotros mismos somos presa de nuestra concepción de "religión". Si ahora tomamos el término árabe din, que se suele traducir por religión, veremos que de hecho sus usos desmienten eso: un árabe por ejemplo diría que un cristiano y un judío tienen din, pero un budista o un pagano griego no tendrían din. Porque din, de la raíz d-ā-n ("contraer una deuda", "deber algo", "tomar prestado algo"), designa "ajuste de cuentas", "juicio", "saldo del cuentas". Cuando el musulmán recita el Corán I:4 «māliki yaūm ad-Dinni» (señor del día del juicio), no quiere decir "señor del día de religión", sino "señor del día del ajuste de cuentas", "señor del día del saldo de cuentas", porque tener din no es tener religión, sino tener una creencia con respecto al "ajuste de cuentas" en un final de la historia en función del cual uno entiende o concibe todos los actos de su vida como contando para cuando ese día llegue. Así, el judío, el cristiano y el musulmán tienen din, porque todos creen en que cada acto que hagan hasta el día de su muerte se les tomará ese día como en un juicio. Ésto es la creencia de verdad, la concepción, que describe una gramática de todos los conceptos que genera ese paradigma o esa "forma de ver". Pero entonces, si el musulmán no se entiende como religioso, ni el judío, ni el budista... ¿por qué describir su cultura desde mi propio marco conceptual si, como se ve, ese marco lo distorsiona constantemente aplicando categorías que no tienen sentido fuera de nuestra propia cultura o nuestra historia?. La historiografía está presa de su 
propia manera de mirar el mundo y comprenderlo, pero entonces no estamos comprendiendo a la comunidad que tratamos de estudiar o el paradigma de esa comunidad, sino que simplemente estamos, presos de nuestra propia manera de comprender las cosas, viendo los aspectos que somos mentalmente capaces de concebir, porque nos resulta inconcebible (a nosotros) que un pueblo no separe religión o estado, o que no tenga estado por ejemplo. Pero un análsis más detenido muestra que los pueblos no se entienden a sí mismos o a otros como teniendo "religión" con independencia de su constitución política, sino que su "religión" es parte indiferenciable de las producciones de la comunidad. Por culpa de tener en la mente y aplicar el concepto "religión" surgen preguntas realmente estúpidas que generan discusiones vacías cómo: ¿qué es religión? ¿el Judaismo es una religión? ¿este es un acto religioso? ¿dónde comienza lo religioso y dónde las costumbres? ¿el Estoicismo es una religión o no? ¿el Budismo es una religión o una forma de vida? ¿qué es la religiosidad? ¿es la religiosidad diferente de la espiritualidad? ¿es la religión un tipo de relación con Dios o con lo sagrado? ¿Sohravardi es un mistico o un filósofo? ¿al-Gazali habla de filosofía o de religión?. Todas estas preguntas se no se resuelven con el esquema propuesto, sino que se disuelven, dejan de tener sentido, porque todas estas preguntas se originan bajo el prejuicio de que la religión es distinta y separable de la constitución política y de la manera de ver las cosas, cuando como vemos, los pueblos no lo han considerado así nunca.

Imaginemos ahora que nos encontramos a un judío por la calle, y éste (que pasa por muchos conflictos internos entre sus pasiones y la ley judía) nos dice: «ha-Shem me hace pasar por muchas penalidades debido a la dureza de la ley que ha dado, pero me da fuerzas para seguir adelante». Ahora realicemos la operación se sustituir "ha-Shem" por "la comunidad", y a frase queda tal que así: «la comunidad me hace pasar por muchas penalidades debido a la dureza de la ley que ha dado, pero me da fuerzas para seguir adelante». Como hemos visto con Freud, la cultura regula las relaciones de los individuos entre sí, luego las leyes (incluida la Sharia, la ley hebraica, la tradición confuciana de las diferentes relaciones entre los miembros de la familia etcétera), que diferencian y legislan las relaciones lícitas e ilícitas entre las personas de una comunidad, son exigencias culturales que garantizan una convivencia "sana". Estas leyes son parte de las producciones de una cultura, como decimos, y la comunidad se encarga de mantener la cultura mediante instituciones que garanticen que todos los individuos se mantienen adheridos a esas leyes a través de una manera de ver, de una manera de entender o representarse el mundo, pero esas instituciones son simultáneamente comunitarias y religiosas, esa es la beyt-keneset de los hebreos, la casa de la reunión, la casa de la asamblea donde todos se juntan a discutir la ley. La ley de Dios es dura porque las exigencias de una vida en comunidad son duras, pero la comunidad al mismo tiempo proporciona los alivios suficientes 
como para llevar la pesadumbre. Freud ha dedicado mucho espacio a esto en el Malestar de la cultura. Pero entonces lo sagrado se convierte, como anticipa revolucionariamente Durkheim, en una hipóstasis de la comunidad misma, y la beyt-keneset se convierte en el lugar donde la comunidad se "hipostatiza" autorregulándose y manteniendo a los miembros dentro de ese modo de pensar.

Si nos detenemos ahora a ver las variedades de la cultura semítica, veremos que las diferencias entre tales y cuales formas de esa misma cultura son a la vez políticas, sociales y doctrinales, al tiempo que lingüísticas por ejemplo. Un cristiano sirio sigue otras leyes que un caballero judío en la misma medida, por ejemplificarlo así, en que los dos hablan un dialecto diferente de la lengua semítica. Un musulmán tiene que hacer una serie de purificaciones antes de entrar en la mezquita los viernes que se diferencian de lo que tenga que hacer un judío que va a la sinagoga el sábado. Un judío sigue unas leyes que se diferencian de las del musulmán. Todas estas diferencias son las que constituyen la línea divisoria visible, y todas estas cosas deberían leerse en conjunto y a la vez: no hay diferencias legales y religiosas y lingüísticas, sino que todas ellas forman parte de lo mismo y no se deberían concebir como separadas, porque ellos no las conciben así.

Esta sección quiere dedicarse al proselitismo, pero para entender lo que deseo explicar acerca del mismo necesito detenerme en lo que yo creo que el funcionamiento de las comunidades en dos aspecto relacionados: $1^{\circ}$, cohesión de una comunidad; $2^{\circ}$ deseos de una comunidad; $3^{\circ}$, actos contingentes o necesarios en una comunidad. En esencia, creo que se puede decir que un comunidad (como ya de hecho he dicho antes) puede ser sujeto de deseos que pueden manifestarse eventualmente en un personaje histórico meramente contingente. Con esto no quiero defender a la comunidad como un ente metafísico, sino más bien deseo expresar lo siguiente: todos los miembros de una comunidad comparten por ser miembros de la misma un paradigma que les proporciona un marco común para entender, exactamente lo mismo que un lenguaje (de hecho el lenguaje formaría la parte más común y visible de este paradigma); lo que significa que, aproximadamente, todos los individuos van a compartir una serie de ideas y opiniones, y sobre todo, deseos. La pertenencia a una comunidad se mide entoces en función de compartir un paradigmal Bild, y su cohesión se mide en términos de deseo de pertenencia a una comunidad (por parte del miembros) y capacidad efectiva de convocatoria (por parte de la institución de esa comunidad). Si concebimos que las cosas se nos presentan como deseables también en función de un paradigma (un sevillano concibe como bueno unos caracoles que para un extranjero pueden ser realmente repulsivos, pero el sevillano, ofreciendo a comer esos caracoles, estaba compartiendo su manjar, es decir, deseando algo bueno para ese otro), entonces, en la medida en que los miembros de una comunidad se 
sientan dentro de ella y deseen pertenecer a ella, podemos decir que esos deseos que todos comparten son deseos de la comunidad como sujeto moral. Esta es la otra gran clave para comprender el fenómeno de la conversión, y también, para entender por qué el personaje histórico es contingente frente al hecho que ejecuta que es necesario. Esto es: por poner un ejemplo, Ahmed Yesevi pudo haber muerto antes de acabar su adiestramiento sufí y con ello no haberse dedicado a expandir el Dar al-Islam por el Turkestán. Esto es contingente, pero lo cierto es que había una comunidad de personas que deseaban lo mismo, lo que implica que si no hubiese sido él, hubiese sido otro el nombre que nos hubiese quedado para la posteridad, luego el hecho era necesario ${ }^{83}$.

Aclarado esto, paso a elaborar lo que a mi juicio son los dos problemas del fenómeno de la conversión: primero, por qué sucede; segundo, cómo funciona. Aquí respondo a la primera cuestión: la conversión sucede por un deseo expreso de una comunidad que ha concebido su propia manera de ver la vida/ paradigma como algo bueno que merece ser compartido. Esto presupone que los hombres que no pertenecen a mi comunidad son iguales a mí en calidad de eventuales depositarios de mi concepciónl Auffasung de mi propia comunidad. Si esto está en las mentes de los miembros de la comunidad, la vocación misionera es espontánea en cada uno de los individuos de dicha comunidad. No tiene que haber una institución que maquine o planee conversiones de otros pueblos para dominarlos o adoctrinarlos, sino que el paradigma me proporciona los elementos necesarios para que sea un bien dentro de mí el querer extender mi forma de vida. En definitiva, el proselitismo es un acto de altruismo social equivalente a ofrecer limosna a los pobres o construir hospitales en países extranjeros.

\section{CÓMO FUNCIONA LA CONVERSIÓN}

El segundo problema, cómo funciona la conversión, es igual de sencillo de explicar y concebir si dejamos de usar el vocabulario tradicional y utilizamos el propuesto. Cuando un miembro de una comunidad sale a extender su forma de vida, lo que hace es enseñar a una comunidad extraña elementos de su paradigma, pero no exporta su paradigma. Cuando un maniqueo va a un turco y le intenta explicar su paradigma, lo que le explica son elementos, o mejor dicho, lo que exporta al turco son esos elementos: una oración, una miniatura, una frase, una coletilla que pueda usar, una plegaria, el hacer una fiesta un determinado día o un libro de texto que deberá leer. Pero entonces el turco no se ha convertido al Maniqueísmo sino que ha asimilado elementos del otro paradigma, sin cambiar el

83 O. Spengler, La decadencia de Occidente, Madrid, 2009, Espasa- Calpe, I, 231-235, es parcialmente la base de esta distinción entre acto contingente y acto necesario, pero mi argumento es diferente y objetivo es diferente, no puedo decir salvo Spengler me inspiró esta idea. 
suyo propio. Porque las creencias que hay de fondo en la mentalidad del maniqueo no han pasado mediante los elementos a construir el paradigma en la mente del otro, sino que el otro está obligado, por su propio paradigma, a interpretar esos elementos desde su propia Vorstellung.

\section{Preguntas y Respuestas}

1 ¿Es esto así?, creo que los ejemplos antes puestos extraídos de la historia de Asia Central son claros: la conversión no existía, existía la asimilación de elementos (como llamar a tu Dios "Allah", rezar cinco veces al día, realizar una serie de ritos), exactamente igual que existen muchos sustantivos y adjetivos en lengua turca que vienen del árabe, sin que la gramática de la lengua turca se haya hecho realmente árabe.

2 ¿Existe entonces la conversión real?, claro que existe, pero requiere mucho más que el proselitismo, requiere la inmersión total y completa de los nuevos miembros de la comunidad en el núcleo de la comunidad matriz de ese paradigma. Aunque es posible, y esto yo no lo tengo claro, que la acumulación sucesiva de elementos de un paradigma extrańo termine convirtiendo el propio, o al menos trastocarlo. En cualquier caso, de lo que sí estoy seguro es de que la conversión es un cambio de cualidad y no de cantidad. Porque una forma determinada de ver la vida se tiene o no se tiene, pero ni hay tonos de grises ni hay varias a la vez, eso está tan claro como que uno o usa una gramática u otra, pero no dos a la vez. En el Tractatus de Wittgenstein ${ }^{84}$ hay un cubo dibujado, pero yo puedo ver dos hechos diferentes en función de donde haga descansar la vista primero; pero desde luego no puedo ver los dos cubos a la vez. Convertir a alguien sería hacerle ver un fenómeno de su realidad cotidiana resaltando otros aspectos, es decir, cambiar su manera de mirar el mismo objeto. Si esto se puede lograr mediante una aglutinación de elementos es algo que requiere una investigación independiente.

3 ¿Por qué se exportan sólo los elementos?, considero que hay dos cosas que determinan este fenómeno: $1^{\circ}$, que el paradigma es inconsciente; $2^{\circ}$, que cuando un misionero exporta su paradigma debe utilizar un lenguaje que se entienda en el paradigma extranjero. Lo primero se hace evidente cuando pensamos en nuestro propio lenguaje: no lo comprendemos sino que lo usamos. Igual que no hace falta un conocimiento de gramática para que el niño hable castellano, igual que no hace falta un conocimiento de biología para mover las piernas al andar, así tampoco hace falta que yo conozca la "gramática" de mi paradigma para que yo lo use; el paradigma es, por tanto, inconsciente. Igual que a los hablantes nativos han de hacer un cursillo sobre su propia lengua para poder enseñarla, así, un misionero debería dar un cursillo sobre su propia cultura cuando intenta realizar conversiones. Lo que un hablante nativo hace cuando pretende enseñar a un

84 L. Wittgenstein, Tractatus logico-philosophicus, Madrid, 2002, Alianza, 5.5423. 
extraño su idioma es señalar las cosas y decir su nombre, pero no sabe explicarte por qué en tal contexto, por ejemplo, la palabra lleva tal o cual terminación, o si tal palabra es ahora objeto directo o indirecto etcétera. En definitiva, que el modo de pensar, la verdadera manera de entender nuestra vida, forma nuestra mente sin que lo percibamos, moldea nuestra voluntad sin que lo percibamos y por tanto difícilmente puede exportarse. A esta inconsciencia de la propia manera de ver la bautizaremos LEY DE WITTGENSTEIN, porque de algún modo está ya en las Investigaciones filosóficas ${ }^{85}$. Con respecto a lo segundo, es lo que he llamado la LEY DE SPINOZA, por haber sido enunciada por el filósofo en su Tratado teológico-político, cap. II. Para Spinoza, el modo en que los profetas dan la palabra de Dios a los hombres, o el modo en que Dios mismo habla a los hombres, debe adaptarse siempre a los oyentes o de lo contrario los oyentes no entenderán nada ${ }^{86}$. Dios se revela según la capacidad de cada uno. Por ejemplo, Dios no podría haber hablado a la humanidad en términos de verdades científicas tipo "Bigbang", porque entonces los oyentes no entenderían nada, sino que para hacerse entender, el profeta debe usar el conocimiento que el pueblo tiene, de modo que usará imágenes del tipo «Dios moldeó al hombre de barro y le sopló para darle vida» porque si dice «el hombre se formó después de milenios de evolución por mecanismos de selección natural», el judío de hace dos milenios no hubiese entendido nada. Hasta aquí Spinoza. Si aplicamos esta norma para comprender los fenómenos de Asia Central, tendremos la herramienta hermenéutica necesaria para describir los fenómenos relativos a la historia de las conversiones, tanto por parte del misionero como por parte del oyente. Así, el misionero por una lado tomará los elementos de su propio paradigma y el oyente por su parte interpretará ese elemento desde su propio paradigma. Propongo una relectura de los ejemplos aducidos relativos a los sufíes y los misioneros nestorianos entre los turcos. Para el turco-mongol, acostumbrado a tener como figura de su vida comunitaria al chamán, entiende que lo sagrado se manifiesta en el chamán mediante signos y poderes que el chamán usa. Cuando el misionero nestoriano va a predicar a los turcos, el misionero debe reducirse al lenguaje de los turcos y mostrar poderes que lo legitimen como portavoz de lo sagrado, y el turco comprenderá ese milagro dentro de su propio paradigma y lo verá como un poderoso chamán, como un portavoz legitimado de lo sagrado. La incomprensión no podía ser mayor: ni

85 Véase la segunda característica que Bocardo, op. cit., 154, señala es que las concepciones pueden «ejercer una tiranía sobre la mente [...] en la obsesión mental que crean al imponer un patrón unitario de descripción, o en la tendencia compulsiva a ver solo un aspecto de la realidad, y forzar una descripción de los hechos que nos vuelva ciegas para reconocer otros aspectos que quedan fuera del ámbito de la representación de una forma particular de ver».

86 De Cristo dice que "acomodó sus razones a las opiniones de unos u otros» (B. Spinoza, Tratado teológico-politico, Madrid, 2012, Alianza, 115). De los profetas: «Dios adaptó las revelaciones a la capacidad y a las opiniones de los profetas» (ibídem, 114). 
el nestoriano es nestoriano cuando habla con el turco ni el turco deja de ser turco cuando habla con el nestoriano. Lo mismo sucede con los sufíes: como ya hemos vistos, los sufíes de Asia Central realizaron prácticas que su público entendiese, porque de lo contrario no serían tomados como portavoces legítimos de lo sagrado; es más, en los casos de Hacı Bektaş y Ahmed Yesevi, posiblemente no es que quieran enseñar el Islam así, es que directamente lo entendieron así. Spinoza nos ha aportado la herramienta herméutica que el historiador necesita para interpretar los fenómenos históricos. Del mismo modo, ahora podríamos interpretar fenómenos ocurridos en otras religiones proselitistas, como el Budismo en el Tibet o el Cristianismo en Europa. Los Himnos a Isis ${ }^{87}$ (culto que se adelantó al Cristianismo en proselitismo en la época de la explosión de los cultos mistéricos) escritos en griego pese a relatar las hazañas y virtudes de una Diosa egipcia son otra muestra más, dado que Isis se heleniza, y pasa a tener atributos que los Griegos consideran que tienen sus propios Dioses ${ }^{88}$. Todo el trasfondo de la historia de Milarepa, por volver a Asia Central, son también otro ejemplo ${ }^{89}$.

4 ¿hay diálogos interculturales?: no. Puede haber exposición de las creencias de cada comunidad (en la medida en la que los portavoces sean conscientes de dichas creencias o al menos las conozcan) pero no, desde luego, un diálogo en sentido casi "nutritivo", de asimilar o enriquecerse de la concepción que se me opone en el diálogo. Spengler, con mucha lucidez, descubre casi el mismo fenómeno que Wittgenstein y describe así el diálogo entre culturas en el aspecto filosófico entre tres filosofías diferentes: «los pensadores árabes de la época más madura —y había entre ellos talentos de primer orden como Alfarabi y Alkabi- demostraron en su polémica contra la teoría aristotélica del ser que el cuerpo, como tal, no necesita de espacio para existir; y definieron la esencia del espacio- - esto es, la manera árabe de entender la extensión-derivándola de la nota «encontrarse en un lugar». Esto no prueba que, frente a Aristóteles y Kant, estuviesen los árabes en el error, o — como solemos llamar a lo que no nos cabe en la cabeza - que pensasen confusamente.

87 Parece que los Himnos a Isis parten de un original compuesto a principio del siglo III a.C. (E. Muñiz Grijalvo, Himnos a Isis, Madrid, 2006, Trotta, 13), pero de hecho la expansión por el Mediterráneo sería posterior, y los Himnos serían un mecanismo para llamar la atención de los Griegos sobre los cultos isíacos (ibídem, 23), igual que después haría San Pablo con el Cristianismo. Más sobre la adaptación de la diosa al mundo heleno en la misma obra, 27-34.

88 Véase al caso que estudía Muñiz Grijalvo de la asimilación de Deméter (ibídem, 25).

$89 \mathrm{Me}$ refiero, por poner a un ejemplo, a toda la magia que aparece en la primera parte de libro, en que se narra como Milarepa aprende ciertos poderes (el poderoso parece ser el del granizo) de un maestro para destruir o dañar a una familia enemiga de la suya propia. El arrepentimiento de Milarepa ante estas acciones serán las que le lleven a dirigirse al maestro Marpa gracias al cual, tras multitud de penalidades, llegará al nirvana. La trama misma de la obra depende de una serie de creencias en poderes mágicos. (traducción de la obra: I. Preciado Idoeta, Historia de Milarepa. Grande y poderoso yogui, Milarepa, 2012, Miraguano). 
Demuestra tan solo que el espíritu árabe poseías otras categorías del mundo. Los pensadores árabes, usando de sus conceptos y términos propios, hubieran podido refutar a Kant con el mismo rigor demostrativo que Kant a ellos; y las dos partes habrían quedado convencidas de la exactitud de sus puntos de vistas ${ }^{90} \%$. Es una pena que Spengler no desarrollase de otra manera (menos metafísica... o menos alemana) esta misma idea porque en mi opinión esto es exactamente lo mismo que dirá Wittgenstein (quien por cierto leyó a Spengler y el mismo reconoce esa influencia aunque no lo cite ${ }^{91}$ en las Investigaciones filosóficas ${ }^{22}$ ).

\section{Movimientos y EVOLUCiones}

La segunda ocasión en que expuse este texto en público, J. A. Antón Pacheco confesaba que le parecía mi descripción o intento de explicación de los hecho un tanto "estático», en sus propias palabras. Esto me pareció efectivamente muy cierto, por ello me ha parecido preciso dedicar unas palabras a lo que podemos llamar "movimientos" o "evoluciones" de una concepción/ paradigma. Dado un grupo aislado, una comunidad que permanezca aislada de otras comunidades, en un mismo clima y circunstancias generales de población, calidad de la tierra de la que dependan \&c., no es posible que haya un cambio sustancial en una concepción, sino que por el contrario, sólo la agotadora tradición oral podría crear lagunas o desperfectos, pero por lo general, no cambiaría ni mucho menos en esencias. Así, culturas enteras más o menos aisladas, han mantenido (en desigual grado) las concepciones de las que se sirvieron sus antepasados. Durkheim da buena cuenta de ello. Ahora bien, ¿cómo se comporta una concepción cuando se enfrenta a otras? ¿qué surge de su encuentro? ¿qué sucede con las formas de vida cuando se encuentran con otras? ¿qué ocurre cuándo cambian las condiciones sociales o económicas de los miembros de una comunidad?. La historia nos ha dado miles de ejemplos ${ }^{93}$. Bajo mi consideración, las concepciones se MUEVEN (en el sentido de que cambian) cuando: $1^{\circ}$, hay causas externas al mismo que aportan nuevos elementos que no son fáciles de interpretar por la concepción dominante; $2^{\circ}$, cuando las condiciones climáticas han alterado el modo de vida en un sentido económico; $3^{\circ}$, cuando hay elementos de concepciones ajenas que han provocado un cambio cualitativo. Considero que las concepciones EVOLUCIONAN cuando la concepción se ha desarrollado madurando en, por

90 O. Spengler, op. cit., I, 272.

91 A. Losev, "Morpho-logical- Investigations: Wittgenstein and Spengler", Philosophia e Journal of Philosophy and Culture,2013. Recurso elecrónico: http://philosophy-e.com/morpho-logicalinvestigations-wittgenstein-and-spengler/ (acceso el día 13/03/2015).

92 Losev hace notar la influencia de Spengler en Investigaciones filosóficas \$\$89-131. Losev, op. cit.

93 En el texto original citaba varios ejemplos que, por necesidad de recortar, he tenido que eliminar. Espero poder colmar de ejemplos estas reflexiones en un lugar más apropiado. 
ejemplo, una teoría de grey filosófica o científica. Siempre ligaré el movimiento de una concepción a fuerzas ajenas, y la evolución a fuerzas internas.

\section{Conclusiones}

Cuando he explicado en qué eran y cómo funcionaban las concepciones, estaba hablando exclusivamente de ello, no estaba negando el hecho de que hubiese movimientos y cambios, sino que hablaba, sincrónicamente por decirlo así, de cómo funcionaban a nivel cultural. La aproximación al estudio de cómo y en qué condiciones las concepciones funcionan es con mucho insuficiente dado el tema, pero considero que lo esencial queda dicho. En cualquier caso, espero poder realizar un estudio mucho más detallado de este último tema en otro lugar y, obviamente, con mayor volumen de información.

Lo único que en mi opinión merece la pena de este escrito se puede resumir en estas vindicaciones:

1. hay que dejar de utilizar el término "religión" en la historiografía.

2. hay que redefinir lo que significa "conversión", describiéndola como un movimiento de elementos en una dirección entre dos paradigmas.

3. el historiador debe liberarse, para hacer una historiografía más adecuada a los fenómenos, de las concepciones en las que se mueve su comunidad.

4. el historiador de las "religiones", o el historiador en general, habría de usar, en vez de "religión o religiones", "paradigma/ concepción".

5. lo mismo se puede decir, siguiendo a Weiers, acerca del uso de "estado", "imperio", "reino", que deben sustituirse por "comunidad" a no ser que esa misma comunidad haya usado esas categorías para entenderse a ella misma.

6. a la hora de hablar (o hacer uso) de términos que aparentemente son "religiosos", (din, beyt-keneset, waqf, chamán, "hijo del cielo") el historiador debe ponderar prudentemente si aplica usar la categoría "religioso/ -a" para ese término o fenómeno después del análisis que hemos hecho. Sea quizás más prudente detenerse a dibujar lo que significa ese elemento para la comunidad en general. Sin dividir o aplicar la categoría "religioso".

\section{Agradecimientos}

Debo a Emilio G. Ferrín, Enrique Hiedra y Pedro González las aportaciones que realizaron la primera vez que expuse el tema en el Observatorio de Religiones Comparadas en Sevilla el sexto día de Marzo del año de 2015. Este texto volvió a exponerse el día vigésimo tercero del mismo mes y año, con muchos cambios, en el seminario Pensamiento Griego e Interculturalidad, donde Jesús de Garay Suárez Llanos y Jose Antonio Antón Pacheco realizaron de nuevo aportaciones que han enriquecido el texto con nuevas problemáticas que antes no estaban presentes. Por último, Enrique Bocardo Crespo me ha ayudado mucho con las lecturas que 
me recomendó así como con sus comentarios. A J. A. Antón Pacheco le debo una especial mención por haberme ofrecido la oportunidad de publicar el texto. Para con todos ellos mi más profundo agradecimiento a la vez que reconocimiento, dado que sin sus aportaciones este trabajo hubiese quedado de hecho muy pobre. 